\title{
Association between inflammation and cancer stem cell phenotype in breast cancer
}

\author{
YOUNG JU JEONG ${ }^{1}$, HOON KYU OH ${ }^{2}$, SUNG HWAN PARK ${ }^{1}$ and JIN GU BONG ${ }^{3}$ \\ Departments of ${ }^{1}$ Surgery and ${ }^{2}$ Pathology, College of Medicine, Catholic University of Daegu, Nam, \\ Daegu 42471; ${ }^{3}$ Department of Surgery, Raphael Hospital, Jung, Daegu 41968, Republic of Korea
}

Received November 10, 2015; Accepted February 23, 2017

DOI: $10.3892 / \mathrm{ol} .2017 .7607$

\begin{abstract}
Inflammation and cancer stem cells (CSCs) are becoming increasingly recognized as components of tumorigenesis in breast cancer. In the present study, the association between inflammation and BCSC phenotype was evaluated in human breast cancer tissue. Immunohistochemical staining for cluster of differentiation (CD)24, 44, 4, 8 and 68 was performed using tissue microarray blocks containing 47 consecutive cases of invasive breast carcinoma and 10 normal breast tissue samples. The levels of inflammatory modulators and cytokines, and intratumoral or peritumoral lymphocyte infiltration, were assessed. BCSCs were defined

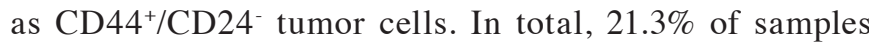
exhibited the $\mathrm{CD} 44^{+} / \mathrm{CD} 24^{-}$phenotype. This phenotype was identified to be significantly inversely associated with lymph node metastasis. In addition, the $\mathrm{CD} 44^{+} / \mathrm{CD} 24^{-}$phenotype was significantly associated with the molecular subtype of breast cancer, and was particularly increased in the basal-like subtype. Furthermore, the $\mathrm{CD} 44^{+} / \mathrm{CD} 24^{-}$phenotype was significantly associated with intratumoral inflammation and tumor-infiltrating $\mathrm{CD}^{+} \mathrm{T}$ cell counts. Notably, tumor-infiltrating $\mathrm{CD}^{+} \mathrm{T}$ cells were significantly increased in patients with the basal-like molecular subtype of breast cancer. In conclusion, the present study identified a significant association between inflammation and the $\mathrm{CD} 44^{+} / \mathrm{CD} 24^{-}$phenotype in breast cancer. These results suggest that the interaction between inflammation and CSCs may affect the tumorigenesis and progression of breast cancer. Further studies are required to clarify the role of inflammation and CSCs in breast cancer.
\end{abstract}

Correspondence to: Professor Young Ju Jeong, Department of Surgery, College of Medicine, Catholic University of Daegu, 17 Duryu Park Road, Nam, Daegu 42471, Republic of Korea E-mail: yjjeong@cu.ac.kr

Key words: inflammation, cancer stem cell, breast cancer, tumor-infiltrating lymphocyte, tumor microenvironment

\section{Introduction}

The association between inflammation and the development of cancer has been suggested for numerous years $(1,2)$. Specifically, in breast cancer inflammation is increasingly recognized as an important component of tumorigenesis. Previous studies have reported that numerous inflammatorymediatorsinfluencebreastcancerdevelopmentand progression (3-7).

There is increasing evidence that cancer stem cells (CSCs) mediate tumor growth and metastasis (8). CSCs possess two main properties, the ability to self-renew and the ability to differentiate into heterogeneous lineages of cancer cells that comprise the tumor. Breast tumors cells that exhibit the properties of CSCs have been termed breast CSCs (BCSCs) $(9,10)$. Previously, it has been suggested that inflammation may regulate $\mathrm{BCSCs}$, and certain immune mediators have been reported to influence BCSC biology (11). There is an investigation into immunotherapies targeting CSCs and an initial report has demonstrated the potential of immunotherapy as a cancer treatment (12); however, the mechanisms underlying these approaches are not yet fully characterized. The majority of previous studies were pre-clinical, and the role of inflammation and CSCs in patients with breast cancer was not well defined. In the present study, the association between inflammation and the BCSC phenotype was evaluated in human breast cancer tissue. In addition, the association between BCSCs and inflammation in the progression of breast cancer was investigated.

\section{Materials and methods}

Patients and tissue microarrays (TMAs). A total of 47 consecutive patients with primary breast cancer who had undergone surgery between May 2008 and November 2011 at Daegu Catholic University Hospital (Daegu, Korea) were included in the present study. The inclusion criteria were as follows: i) Patient had primary breast cancer; ii) patient provided informed consent; iii) patient had undergone surgery, including breast conserving surgery or mastectomy; iv) patient had a tissue sample available following surgery. All patients were female; the mean age of the patients was $55.77 \pm 13.47$ years (range, 34-90 years).

All data was retrospectively analyzed. All tissue specimens had previously been formalin fixed, paraffin embedded, 
stained with hematoxylin and eosin, and reviewed by an experienced pathologist. The clinical information of the patients and their tumor characteristics, including tumor size, nodal status, histological grade, lymphovascular invasion status and other prognostic factors, were evaluated based on medical records, and pathological reports. Breast cancer staging was assessed according to the seventh edition of the American Joint Committee on Cancer staging manual for breast cancer (13). Histologic grade was assessed using the Nottingham grading system (14). Ethical approval for the study was obtained from the Institutional Review Board of Daegu Catholic University Hospital. Written informed consent was obtained from all patients.

TMAs were constructed using representative paraffin blocks of 47 cases of invasive breast carcinoma and 10 normal breast tissue samples obtained from the same patients, following the method described in our previous study (15).

Immunohistochemical staining. Immunohistochemical staining was performed on TMA sections, including cancer and normal tissue, using the Bond Polymer Intense Detection system (Leica Microsystems, Inc., Buffalo Grove, IL, USA) according to the manufacturer's protocol with minor modifications. The TMA blocks were cut into $5-\mu \mathrm{m}$-thick sections and deparaffinized with Bond Dewax solution (Leica Microsystems, Inc.). An antigen retrieval procedure was performed using Bond ER Solution (Leica Microsystems, Inc.) for $30 \mathrm{~min}$ at $100^{\circ} \mathrm{C}$.

Endogenous peroxidase activity was quenched with hydrogen peroxide for $5 \mathrm{~min}$ at $25^{\circ} \mathrm{C}$. Sections were then incubated for $15 \mathrm{~min}$ at room temperature with primary monoclonal antibodies directed against the following proteins: cluster of differentiation (CD)24 (dilution, 1:20; cat. no. SC-7034; clone C-20; Santa Cruz Biotechnology, Inc., Dallas, TX, USA), CD44 (dilution, 1:1,000; cat. no. NBP1-47386; clone, 8E2F3; Novus Biologicals, LLC, Littleton, CO, USA), CD4 (ready-to-use dilution; cat. no. PA0368; clone 4B12; Leica Biosystems, Inc., Wetzlar, Germany), CD8 (dilution 1:200; cat. no. M7103; clone C8/144B), CD68 (dilution, 1:200; cat no. M0876; clone, PG-M1), epidermal growth factor receptor (EGFR; dilution, 1:100; cat. no. M7239; clone, EGFR.25), apoptosis regulator Bcl-2 (dilution, 1:4; cat. no. IR614; clone, 124), human epidermal growth factor receptor 2 (HER2; dilution, 1:250; cat. no. A048529-1; clone, A0485; all from Dako; Agilent Technologies, Inc.), estrogen receptor (ER; dilution, 1:100; cat. no. NCL-L-ER-6F11; clone, 6F11), progesterone receptor (PR; dilution, 1:100; cat. no. NCL-L-PGR-312; clone, 16; both from Novocastra; Leica Biosystems, Inc.), proliferation marker protein Ki-67 (dilution, 1:200; cat. no. 275R-16; clone, MM1-L; Sigma-Aldrich; Merck KGaA) and tumor antigen p53 (dilution, 1:200; cat. no. 18-0129; clone, BP53.12; Invitrogen; Thermo Fisher Scientific, Inc., Waltham, MA, USA).

The samples were then treated with a biotin-free polymeric horseradish peroxidase-linker antibody conjugate system (Bond Polymer Refine Detection; ready-to-use dilution; cat. no. DS9800; Leica Biosystems, Inc.). Staining was performed in a Bond-Max Automatic Slide Stainer (Leica Microsystems, Inc.). A BX50 light microscope (Olympus Corporation, Tokyo, Japan) was used to visualize staining at x400 magnification; the stained cells were manually counted.
Expression levels of CD24 and CD44 were graded on staining intensity and the proportion of positively stained tumor cells. The levels of immunopositivity were semiquantitatively scored as follows: 0 , No staining; $1^{+}$, minimal staining intensity, $<10 \%$ of cells positively stained; $2^{+}$, moderate staining intensity, $10-50 \%$ of cells positively stained and $3^{+}$, marked, staining intensity, $>50 \%$ of cells positively stained. Scores of 0 and 1 were designated as negative, and 2 and 3 as positive. Examples of this staining are illustrated in Fig. 1. BCSCs were defined as CD44 $/$ CD24- tumor cells. For ER and PR, nuclear staining in $\geq 1 \%$ of tumor cells was considered positive. Cytoplasmic and membranous staining of any intensity in $\geq 5 \%$ of the tumor cells was considered as positive for Bcl-2. Membranous staining for HER2 with strong complete staining in $30 \%$ of the tumor cells was regarded as HER2 overexpression. p53 staining was scored positive if $\geq 5 \%$ of the cells were stained with a strong intensity. The Ki-67 labeling index was expressed as a percentage and was graded as high if the number of positively stained cells was $\geq 14 \%$.

The CD4, CD8 and CD68 immunostained TMA sections were evaluated under a microscope and the number of $\mathrm{CD}^{+}$ and $\mathrm{CD}^{+} \mathrm{T}$ cells and $\mathrm{CD} 68^{+}$macrophages were counted in the stroma and cancer cell nests. Examples of this staining are illustrated in Fig. 2. Intratumoral (in the tumor cell nest) or peritumoral (in the stroma around the tumor) lymphocyte infiltration was semiquantitatively graded as follows: 0 , No lymphocyte infiltration; 1 , mild scattered lymphocyte infiltration in either stroma or tumor cell nest; 2 , moderate lymphocyte infiltration with some lymph follicle formation; 3 , dense and widespread lymphocyte infiltration.

Reverse transcription polymerase chain reaction (RT-PCR). The levels of inflammatory modulators and cytokines, including tumor necrosis factor (TNF)- $\alpha$, interleukin (IL)-2, -4 and -6 , interferon (IFN) $-\gamma$ and nuclear factor (NF) $-\kappa B$ p50 were assessed by the levels of mRNA transcripts in frozen tissue using RT-PCR. Total RNA was extracted from frozen breast cancer tissues using Trizol reagent (cat. no. A33250; Invitrogen; Thermo Fisher Scientific, Inc.). Subsequent to lysing and homogenizing samples in the Trizol reagent, the samples were incubated for $5 \mathrm{~min}$ at room temperature. Chloroform was added to the samples, and the samples were agitated for $15 \mathrm{sec}$, then incubated for 2-3 $\mathrm{min}$ at room temperature. Following centrifugation for $5 \mathrm{~min}$ at 12,000-16,000 x g at $4^{\circ} \mathrm{C}$, the RNA in the samples was precipitated by adding isopropanol. The samples were washed with in $75 \%$ ethanol then the RNA was dissolved with RNase-free water. The RNA was quantified by measuring absorbance at 260 and $280 \mathrm{~nm}$.

To determine the expression of ALCAM, inflammatory modulators and cytokines, reverse transcription of the total RNA was performed. First-strand complementary (c)DNA was generated using a commercial kit (Superscript II RNase H-reverse transcriptase, cat no. 18064071; Invitrogen; Thermo Fisher Scientific, Inc.) used according to the manufacturer's protocol. For the PCR of ALCAM, TNF- $\alpha$, IL-4, IFN- $\gamma$ and $\mathrm{NF}-\kappa \mathrm{B}$ p50, the following primers were used: ALCAM, forward, 5'-CAAGACAACCAAGGCTGACA-3'; reverse, 5'-CGCAGACATAGTTTCCAGCA-3'; TNF- $\alpha$, forwards, 5'-CССTCAACСТCTTCTGGCTC-3'; reverse, 5'-AGGCAG CTCCTACATTGGGT-3'; IL-2, forwards, 5'-GCAACTCCT 

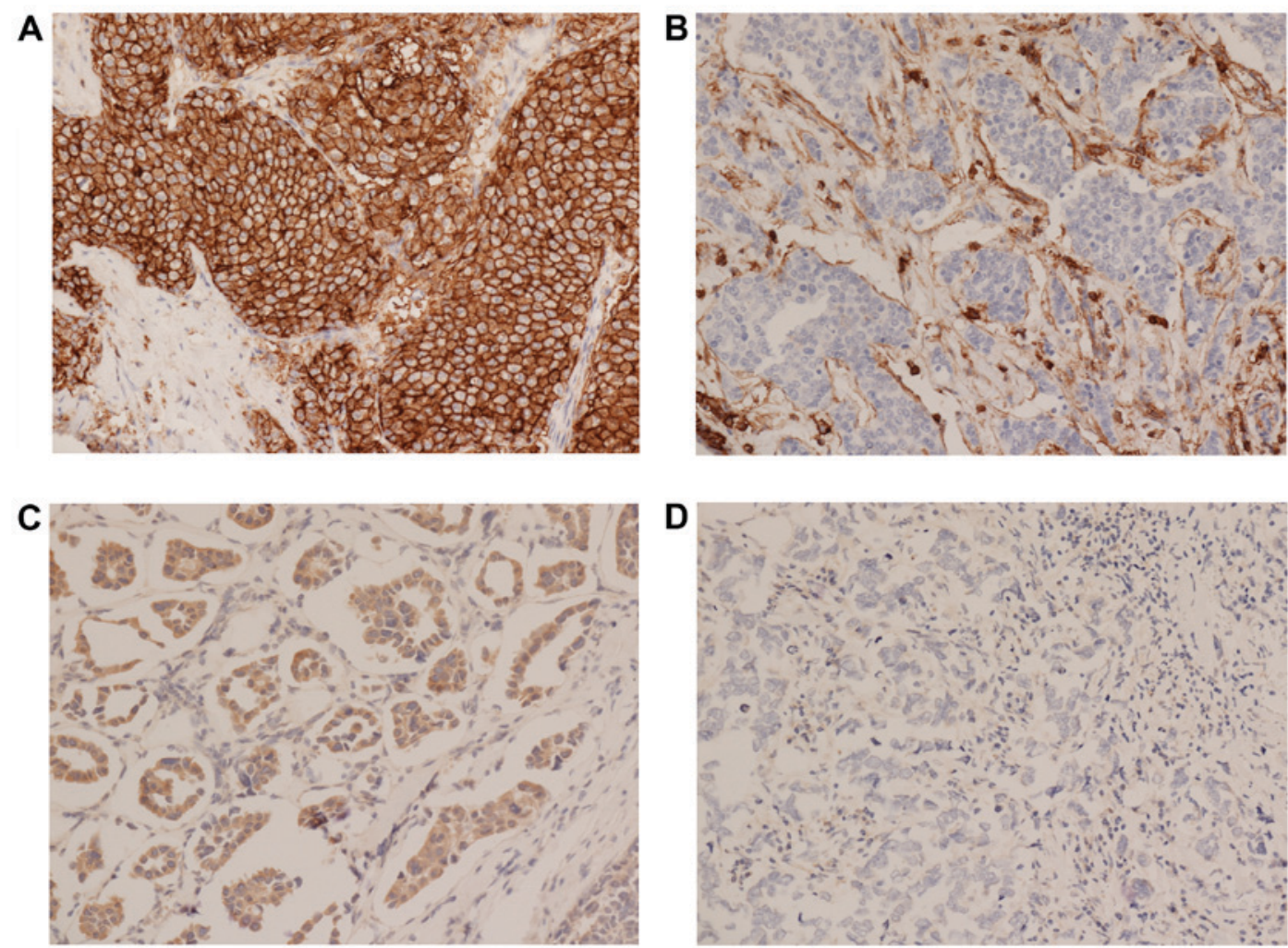

Figure 1. Immunohistochemical staining for CD24 and CD44 in breast cancer tissue. The expression level was graded on the staining intensity and the proportion of positively stained tumor cells (magnification, x400). (A) Immunopositive and (B) immunonegative CD44 expression results. (C) Immunopositive and (D) immunonegative CD24 expression results. CD, cluster of differentiation.
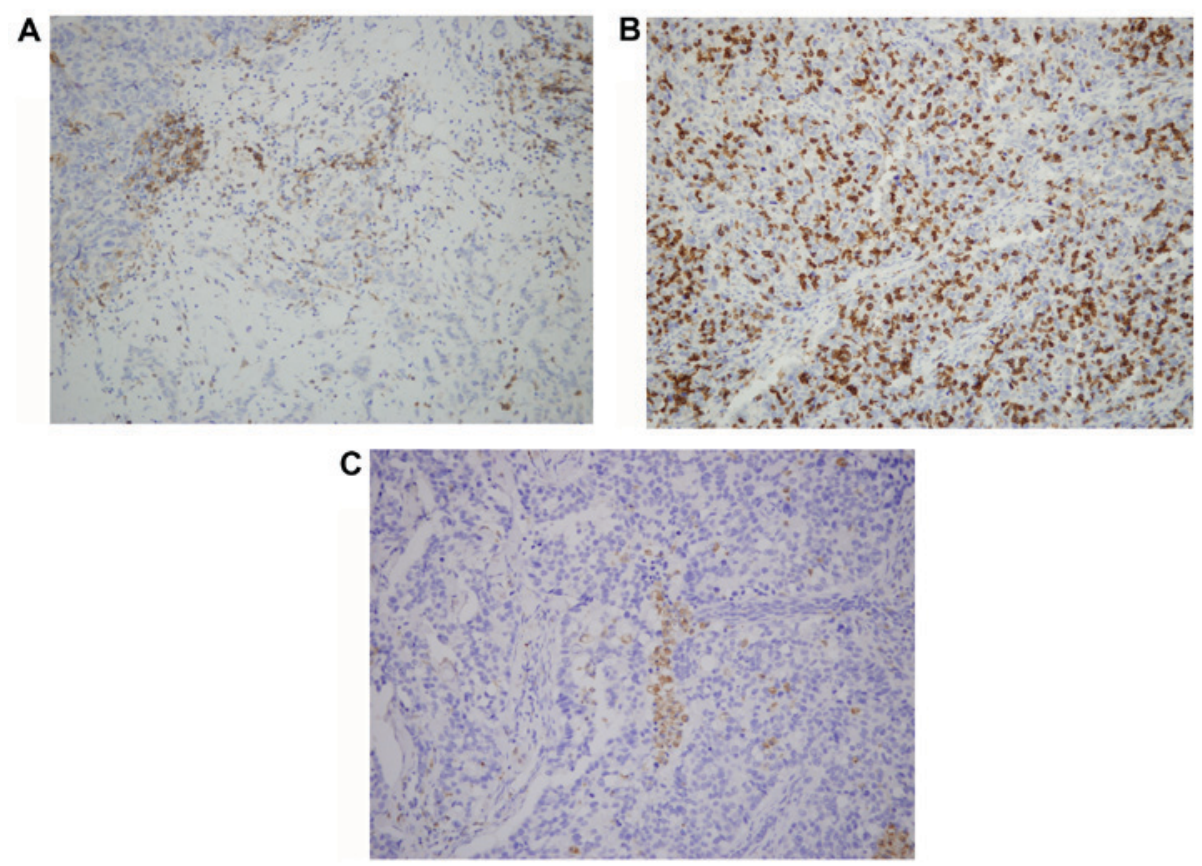

Figure 2. Immunohistochemical staining for CD4, CD8 and CD68 in breast cancer tissue (magnification, $\mathrm{x} 400$ ). The immunostained sections represent positive staining for (A) $\mathrm{CD} 4^{+} \mathrm{T}$ cells, (B) $\mathrm{CD} 8^{+} \mathrm{T}$ cells and (C) $\mathrm{CD} 68^{+}$macrophages. $\mathrm{CD}$, cluster of differentiation.

GTCTTGCATTG-3'; reverse, 5'-TGCTTTGACAAAAGG TAATCCA-3'; IL-4, forwards, 5'-ACTGCTTCCCCCTCT GTTCT-3'; reverse, 5'-TGATCGTCTTTAGCCTTTCCA-3'; IL-6, forwards, 5'-TACCCCCAGGAGAAGATTCC-3'; reverse, 5'-AAAGCTGCGCAGAATGAGAT-3'; interferon- $\gamma$, forwards, 5'-TTGGCTTTTCAGCTCTGCAT-3'; reverse, 5'-CTGTTTTAGCTGCTGGCGAC-3'; NF-kB p50, forwards, 5'-CACCTAGCTGCCAAAGAAGG-3'; reverse, 5'-TCAGCC 
Table I. Clinicopathological characteristics of patients with breast cancer.

\begin{tabular}{|c|c|}
\hline Clinicopathological characteristic & Value \\
\hline $\begin{array}{l}\text { Age, years }[\text { mean } \pm \text { standard } \\
\text { deviation (range)] }\end{array}$ & $55.77 \pm 13.47(34-90)$ \\
\hline \multicolumn{2}{|l|}{ Menopausal status, n (\%) } \\
\hline Premenopausal & $17(38.6)$ \\
\hline Postmenopausal & $27(61.4)$ \\
\hline $\begin{array}{l}\text { Tumor size, } \mathrm{cm}[\text { mean } \pm \text { standard } \\
\text { deviation (range)] }\end{array}$ & $1.97 \pm 1.04(0.10-4.50)$ \\
\hline \multicolumn{2}{|l|}{ Histologic grade, $\mathrm{n}(\%)$} \\
\hline I & $8(17.0)$ \\
\hline II & $12(25.5)$ \\
\hline III & $27(57.5)$ \\
\hline \multicolumn{2}{|l|}{ Nodal involvement, n (\%) } \\
\hline Negative & $29(61.7)$ \\
\hline Positive & $18(38.3)$ \\
\hline \multicolumn{2}{|l|}{ Distant metastasis, $\mathrm{n}(\%)$} \\
\hline Negative & $45(95.7)$ \\
\hline Positive & $2(4.3)$ \\
\hline \multicolumn{2}{|l|}{ Tumor stage, n (\%) } \\
\hline I & $18(40.0)$ \\
\hline IIA & $15(33.3)$ \\
\hline IIB & $9(20.0)$ \\
\hline IIIA & $2(4.5)$ \\
\hline IIIB & $0(0.0)$ \\
\hline IIIC & $1(2.2)$ \\
\hline IV & $0(0.0)$ \\
\hline \multicolumn{2}{|l|}{ Molecular subtype, n (\%) } \\
\hline Luminal A & $9(22.0)$ \\
\hline Luminal B & $23(56.1)$ \\
\hline HER2 & $6(14.6)$ \\
\hline Basal-like & $3(7.3)$ \\
\hline \multicolumn{2}{|l|}{ Lymphovascular invasion, n (\%) } \\
\hline Negative & $27(57.4)$ \\
\hline Positive & $20(42.6)$ \\
\hline \multicolumn{2}{|l|}{ ER expression status, n (\%) } \\
\hline Negative & $15(31.9)$ \\
\hline Positive & $32(68.1)$ \\
\hline \multicolumn{2}{|l|}{ PR expression status, $\mathrm{n}(\%)$} \\
\hline Negative & $10(21.3)$ \\
\hline Positive & $37(78.7)$ \\
\hline \multicolumn{2}{|l|}{ HER 2 overexpression status, n (\%) } \\
\hline Negative & $24(57.1)$ \\
\hline Positive & $18(42.9)$ \\
\hline \multicolumn{2}{|l|}{ Ki-67 index, n (\%) } \\
\hline$<14 \%$ & $2(4.3)$ \\
\hline$\geq 14 \%$ & $44(95.7)$ \\
\hline
\end{tabular}

ER, estrogen receptor; PR, progesterone receptor; HER2, human epidermal growth factor receptor 2 .
Table II. Immunohistochemical staining results for CD44 and CD24.

\begin{tabular}{lr}
\hline Tumor cell phenotype & No. of patients $(\%)$ \\
\hline $\mathrm{CD} 44^{+} / \mathrm{CD} 24^{-}$ & $10(21.3)$ \\
$\mathrm{CD}^{+} / \mathrm{CD} 24^{+}$ & $9(19.1)$ \\
$\mathrm{CD} 44^{-} / \mathrm{CD} 24^{+}$ & $22(46.8)$ \\
$\mathrm{CD} 44^{-} / \mathrm{CD} 24^{-}$ & $6(12.8)$ \\
\hline
\end{tabular}

$\mathrm{CD}$, cluster of differentiation.

AGCTGTTTCATGTC-3'. $\beta$-actin was used as a reference gene and the primer was as follows: Forwards, 5'-AGGGTG TGATGTGGGTATGG-3'; reverse, 5'-CAGGATCTTCAT GAGGTAGTC-3'.

PCR was performed with $1 \mu \mathrm{l}$ of cDNA and $0.4 \mathrm{U}$ Taq polymerase (cat. no. \#18038042; Thermo Fisher Scientific, Inc.). The thermocycler settings were as follows: An initial temperature of $94^{\circ} \mathrm{C}$ for $2 \mathrm{~min}$, then 35 cycles of $94^{\circ} \mathrm{C}$ for $30 \mathrm{sec}, 65^{\circ} \mathrm{C}$ for $30 \mathrm{sec}$ and $72^{\circ} \mathrm{C}$ for $1 \mathrm{~min}$. PCR products were analyzed by agarose gel electrophoresis and visualized with ethidium bromide staining.

Statistical analysis. Statistical analyses were performed using SPSS software (version 15.0; SPSS, Inc., Chicago, IL, USA). A one-sample Kolmogorov-Smirnov test was used to evaluate the distribution of continuous parameters. The association between BCSC phenotype and the number of inflammatory cells was assessed using a Student's t-test for $\mathrm{CD}^{+} \mathrm{T}$ cells and $\mathrm{CD}^{+} 8^{+}$macrophages and a non-parametric Mann-Whitney U test for $\mathrm{CD}^{+} \mathrm{T}$ cells. The association between other inflammatory modulators and the BCSC phenotype was assessed using a $\chi^{2}$ test for intratumoral and peritumoral inflammation, and Fisher's exact test for TNF- $\alpha$, IL-4 and NF-kB p50 expression status. The association between the BCSC phenotype and the clinicopathological characteristics of the patients was analyzed using the Chi-square test for categorical data, including menopausal state, $\mathrm{T}$ stage, node metastasis, histologic grade, lymphovascular invasion, ER, PR, Bcl-2, p53 and EGFR expression status, HER2 overexpression status, Ki-67 index and molecular subtype. All tests were two-tailed. $\mathrm{P}<0.05$ was considered to indicate a statistically significant difference.

\section{Results}

The clinicopathological characteristics of the patients included in the present study are illustrated in Table I. The mean age of the patients with breast cancer was $55.77 \pm 13.47$ years (range, 34-90 years). All cases were categorized into four groups according to the immunohistochemical results for CD44 and CD24 (Table II). Of the 47 patients, 10 (21.3\%) exhibited the BCSC phenotype (CD44 $\left.{ }^{+} / \mathrm{CD} 24^{-}\right)$. CD44 positivity was significantly higher in postmenopausal women compared with in premenopausal women $(\mathrm{P}=0.004$; data not shown). Intratumoral inflammation was significantly more frequent in the CD44-negative groups $(\mathrm{P}=0.018)$ compared with CD44-positive groups (data not shown). 
Table III. Clinicopathological characteristics associated with a $\mathrm{CD} 44^{+} / \mathrm{CD} 24^{-}$phenotype in invasive breast cancer tissue samples.

\begin{tabular}{lcc}
\hline $\begin{array}{l}\text { Clinicopathological } \\
\text { characteristic }\end{array}$ & $\begin{array}{c}\mathrm{CD} 44^{+} / \mathrm{CD} 24^{-} \\
\text {positive patients }(\%)\end{array}$ & P-value \\
\hline
\end{tabular}

\begin{tabular}{lcc}
\hline Menopausal state & & 0.057 \\
Pre-menopausal & 5.9 & \\
Post-menopausal & 29.6 & \\
\hline
\end{tabular}

\section{T stage}

$\leq \mathrm{T} 1$

$\geq \mathrm{T} 2$

25.9

15.0

Node metastasis

Negative

Positive

Histologic grade

$$
1
$$

2

3

Lymphovascular invasion

\section{Negative}

Positive

ER expression status

Negative

Positive

PR expression status

Negative

Positive

HER2 overexpression status

Negative

Positive

Bcl-2 expression status

Negative

Positive

p53 expression status

Negative

Positive

Ki-67 index

$<10 \%$

$\geq 10 \%$

EGFR expression status

Negative

Positive

Molecular subtype

Luminal A

Luminal B

HER2

Intratumoral inflammation

Negative

Positive

Peritumoral inflammation

Negative
31.0

5.6

50.0

16.7

14.8

15.0

26.7

18.8

40.0

16.2

29.2

16.7

20.5

28.6

20.0

50.0

20.5

19.4

27.3

44.4

\section{7}

33.3

66.7

50.0

14.3

0.038

0.092

(n)

0.366

0.536

8

$$
0.103
$$

0.609

0.156

50.0

Table III. Continued.

\begin{tabular}{lcr}
\hline $\begin{array}{l}\text { Clinicopathological } \\
\text { characteristic }\end{array}$ & $\begin{array}{r}\text { CD 44+/C D 24- } \\
\text { positive patients (\%) }\end{array}$ & P-value \\
\hline Positive & 18.8 \\
\hline
\end{tabular}

ER, estrogen receptor; PR, progesterone receptor; HER2, human epidermal growth factor receptor 2; EGFR, epidermal growth factor receptor; Ki-67, proliferation marker protein $\mathrm{Ki}-67$; Bcl-2, apoptosis regulator $\mathrm{Bcl}-2$; $\mathrm{p} 53$, cellular tumor antigen $\mathrm{p} 53$.

Table IV. Association between a CD $44^{+} / \mathrm{CD} 24^{-}$phenotype and inflammatory markers in invasive breast cancer tissue samples.

CD44+/CD24- tumor cell phenotype

Inflammatory marker $\quad$ Positive Negative P-value

TNF- $\alpha$ expression status, $\mathrm{n}$

$\begin{array}{llll}\text { Negative } & 2 & 13 & 0.362 \\ \text { Positive } & 8 & 24 & \\ \text { IL-4 expression status, } n & & & \\ \quad \text { Negative } & 4 & 18 & 0.627 \\ \text { Positive } & 6 & 19 & \end{array}$

NF- $\kappa$ B p50 expression status, $n$

$\begin{array}{lccc}\text { Negative } & 0 & 2 & 0.452 \\ \text { Positive } & 10 & 35 & \\ \text { CD4 }{ }^{+} \text {T cell count, mean } & 9.2 & 31.7 & 0.003 \\ \text { CD8 }^{+} \text {T cell count, mean } & 64.0 & 120.3 & 0.110 \\ \text { CD68+ macrophage count, mean } & 25.6 & 31.9 & 0.505\end{array}$

TNF- $\alpha$, tumor necrosis factor- $\alpha$; IL-4, interleukin-4; NF-кB p50, nuclear factor $\mathrm{\kappa B} \mathrm{p} 50$; $\mathrm{CD}$, cluster of differentiation.

A CD44+CD24- phenotype was significantly inversely associated with lymph node metastasis $(\mathrm{P}=0.038$; Table III). The $\mathrm{CD} 44^{+} / \mathrm{CD} 24^{-}$phenotype was also significantly associated with the molecular subtype of breast cancer $(\mathrm{P}=0.042)$, being particularly more abundant in the basal-like subtype (Table III). In addition, the presence of CD $44^{+} / \mathrm{CD} 24^{-}$tumor cells was associated with intratumoral inflammation $(\mathrm{P}=0.032$; Table III) and tumor-infiltrating $\mathrm{CD}^{+} \mathrm{T}$ cell counts $(\mathrm{P}=0.003$; Table IV).

Analysis of the clinicopathological significance of inflammatory mediators and inflammatory cells demonstrated that tumor-infiltrating $\mathrm{CD}^{+} \mathrm{T}$ cells were significantly increased in patients with basal-like subtype of breast cancer $(\mathrm{P}=0.037)$ compared with other molecular subtypes (data not shown).

\section{Discussion}

There is increasing evidence that inflammation and CSCs are associated with carcinogenesis in numerous tumor types (11,16-19). Recent studies have suggested an association 
between inflammation within the tumor microenvironment and CSCs $(17,19)$; however, the effect of inflammation on CSCs has yet to be fully determined. Blaylock (19) reported that inflammation is essential to cancer induction through its mutagenic effects on stem cell DNA. Shigdar et al (17) demonstrated that inflammatory response and stimuli from immune cells, including cytokines, cause cancer cells to dedifferentiate into CSCs through several signaling pathways, including the $\mathrm{NF}-\kappa \mathrm{B}$ signaling pathway. In breast cancer, several studies have reported that inflammatory signaling within the tumor microenvironment affects CSCs (20-23). Particularly, IL-6 has been reported to induce epithelial-mesenchymal transition, which has been implicated in the generation of a stem cell phenotype $(20,21)$. The main inflammatory cells in the tumor microenvironment are lymphocytes and macrophages, and the main inflammatory cytokines include TNF- $\alpha$, IL-6, IL- 8 and IFN- $\gamma$. Based on the results of previous in vitro studies (20-23), the association between inflammation and CSCs in human breast cancer tissue was analyzed in the present study. The results of the current study demonstrated that intratumoral inflammation and tumor-infiltrating $\mathrm{CD}^{+} \mathrm{T}$ cell counts are associated with CSCs in breast cancer. Typically, activated Th1 cells secrete TNF- $\alpha$, IL- 2 , TGF- $\beta$ and IFN- $\gamma$, and activated Th2 cells secrete IL-4, -5, -6, -10 and -13 (24,25). In combination with the results of previous studies, the results of the current study suggest that tumor-infiltrating lymphocytes are implicated in the generation of CSCs through their secretion of inflammatory cytokines.

It has been suggested that CSCs mediate tumor growth and metastasis $(8,10)$. However, the prognostic significance of CSCs in breast cancer remains unclear. Previous studies have reported that BCSCs are associated with the basal-like molecular subtype of breast cancer and a poor clinical outcome (26,27). However, Mylona et al (28) revealed that BCSCs are associated with a lack of lymph node metastasis and an improved clinical outcome. Furthermore, Abraham et al (29) reported that BCSCs were not associated with the clinical outcome. Notably, consistent with these previous studies, the results of the present study demonstrated that a BCSC phenotype (CD44 $\left.{ }^{+} / \mathrm{CD} 24^{-}\right)$was significantly associated with the basal-like molecular subtype of breast cancer, which confers a poor prognosis, whereas it was significantly inversely associated with lymph node metastasis. These results suggest that BCSCs may be able to initiate tumorigenesis (30), but that signaling pathways that modulate BCSCs, and interactions between BCSCs and the tumor microenvironment, may affect breast cancer progression. Further studies are required to clarify the prognostic significance of CSC phenotype in breast cancer.

It has been recognized that inflammatory mediators in the tumor microenvironment affect breast cancer development and progression (3-7,31). Previous studies have revealed that cytotoxic T lymphocytes and natural killer cells exhibit antitumor activity against breast cancer (32-34). However, numerous studies $(31,35-37)$ have demonstrated mechanisms by which breast tumors avoid antitumor immune responses; protumorigenic inflammation in breast cancer has been reported (31). The inflammatory mediators in breast carcinogenesis include proinflammatory cytokines and chemokines, including IL-1, IL-6, IL-8, TNF- $\alpha$, MCP-1, CCL5 and CXCL1/2 $(3,6,7)$.
Furthermore, previous studies have suggested that $\mathrm{CD}^{+} \mathrm{T}$ cells exhibit antitumor activity in breast cancer, which is dependent on the breast cancer subtype $(38,39)$. Liu et al (38) reported that $\mathrm{CD}^{+} \mathrm{T}$ cell infiltration was associated with improved patient survival in basal-like, but not non-basal, triple negative breast cancer. In the current study, the clinicopathological significance of inflammatory mediators and inflammatory cells were investigated, and tumor-infiltrating $\mathrm{CD}^{+} \mathrm{T}$ cells were revealed to be increased in patients with the basal-like subtype of breast cancer compared with other subtypes. However, it was not possible to analyze the prognostic role of tumor-infiltrating $\mathrm{CD}^{+} \mathrm{T}$ cells in basal-like breast cancer in the current study. Further studies investigating the mechanism by which inflammation influences the progression of different breast cancer subtypes are warranted.

Although preliminary evidence suggests that inflammation and BCSCs are associated with breast carcinogenesis, there is limited data available. The acquisition of more clinical evidence is important for designing effective therapies and identifying improved therapeutic targets for patients with breast cancer. The present study analyzed the association between inflammation and the BCSC phenotype in human breast cancer tissue. However, the results of the current study were limited due to a relatively small sample size, and the clinical significance of these results requires further evaluation.

In conclusion, the present study identified significant associations between inflammation and the BCSC phenotype in breast cancer. The results suggest that the interaction between inflammation and BCSCs may affect tumorigenesis, in addition to the progression of breast cancer. Further studies are required to clarify the role of inflammation and BCSCs in breast cancer.

\section{Acknowledgements}

The authors wish to thank Young Chae Chang (Research Institute of Biomedical Engineering and Department of Medicine, Catholic University of Daegu School of Medicine, Daegu, Korea) and Hyun Ji Cho (Research Institute of Biomedical Engineering and Department of Medicine, Catholic University of Daegu School of Medicine, Daegu, Korea) for their technical support and interpretation of data. The present study was supported by a grant from the Daegu-Gyeongbuk Surgical Society research foundation, Korea.

\section{References}

1. Balkwill $\mathrm{F}$ and Mantovani A: Inflammation and cancer: Back to Virchow? Lancet 357: 539-545, 2001.

2. Arias JI, Aller MA and Arias J: Cancer cell: Using inflammation to invade the host. Mol Cancer 6: 29, 2007.

3. Soria G, Ofri-Shahak M, Haas I, Yaal-Hahoshen N, Leider-Trejo L, Leibovich-Rivkin T, Weitzenfeld P, Meshel T, Shabtai E, Gutman M and Ben-Baruch A: Inflammatory mediators in breast cancer: Coordinated expression of TNF- $\alpha$ \& IL- $1 \beta$ with CCL2 \& CCL5 and effects on epithelial-to-mesenchymal transition. BMC Cancer 11: 130, 2011.

4. Lewis CE and Hughes R: Inflammation and breast cancer. Microenvironmental factors regulating macrophage function in breast tumours: Hypoxia and angiopoietin-2. Breast Cancer Res 9: 209, 2007.

5. Lin EY and Pollard JW: Tumor-associated macrophages press the angiogenic switch in breast cancer. Cancer Res 67: 5064-5066, 2007. 
6. Soria G and Ben-Baruch A: The inflammatory chemokines CCL2 and CCL5 in breast cancer. Cancer Lett 267: 271-285, 2008.

7. Goldberg JE and Schwertfeger KL: Proinflammatory cytokines in breast cancer: Mechanisms of action and potential targets for therapeutics. Curr Drug Targets 11: 1133-1146, 2010.

8. Korkaya H, Kim GI, Davis A, Malik F, Henry NL, Ithimakin S, Quraishi AA, Tawakkol N, D'Angelo R, Paulson AK, et al: Activation of an IL6 inflammatory loop mediates trastuzumab resistance in HER2 ${ }^{+}$breast cancer by expanding the cancer stem cell population. Mol Cell 47: 570-584, 2012.

9. Iqbal J, Chong PY and Tan PH: Breast cancer stem cells: An update. J Clin Pathol 66: 485-490, 2013.

10. Clarke MF, Dick JE, Dirks PB, Eaves CJ, Jamieson CH, Jones DL, Visvader J, Weissman IL and Wahl GM: Cancer stem cells-perspectives on current status and future directions: AACR Workshop on cancer stem cells. Cancer Res 66: 9339-9344, 2006.

11. Boyle ST and Kochetkova M: Breast cancer stem cells and the immune system: Promotion, evasion and therapy. J Mammary Gland Biol Neoplasia 19: 203-211, 2014

12. Gammaitoni L, Leuci V, Mesiano G, Giraudo L, Todorovic M, Carnevale-Schianca F, Agiletta M and Sangiolo D: Immunotherapy of cancer stem cells in solid tumors: Initial findings and future prospective. Expert Opin Biol Ther 14: 1259-1270, 2014.

13. AJCC Cancer Staging Manual. 7th edition. Edge SB, Byrd DR, Compton CC, Fritz AG, Greene FL and Trotti FL (ed). Springer-Verlag, New York, pp347-377, 2010.

14. Elston CW and Ellis IO: Pathological prognostic factors in breast cancer I. The value of histological grade in breast cancer: Experience from a large study with long-term follow-up. Histopathology 19: 403-410, 1991.

15. Jeong YJ, Jeong HY, Bong JG, Park SH and Oh HK: Low methylation levels of the SFRP1 gene are associated with the basal-like subtype of breast cancer. Oncol Rep 29: 1946-1954, 2013.

16. Brabletz T: EMT and MET in metastasis: Where are the cancer stem cells? Cancer Cell 22: 699-701, 2012.

17. Shigdar S, Li Y, Bhattacharya S, O'Connor M, Pu C, Lin J, Wang T, Xiang D, Kong L, Wei MQ, et al: Inflammation and cancer stem cells. Cancer Lett 345: 271-278, 2014.

18. Vermeulen L, De Sousa Melo E, van der Heijden M, Cameron K, de Jong JH, Borovski T, Tuynman JB, Todaro M, Merz C, Rodermond $\mathrm{H}$, et al: Wnt activity defines colon cancer stem cells and is regulated by the microenvironment. Nat Cell Biol 12: 468-476, 2010.

19. Blaylock RL: Cancer microenvironment, inflammation and cancer stem cells: A hypothesis for a paradigm change and new targets in cancer control. Surg Neurol Int 6: 92, 2015.

20. Iliopoulos D, Hirsch HA, Wang G and Struhl K: Inducible formation of breast cancer stem cells and their dynamic equilibrium with non-stem cancer cells via IL6 secretion. Proc Natl Acad Sci USA 108: 1397-1402, 2011

21. Sullivan NJ, Sasser AK, Axel AE, Vesuna F, Raman V, Ramirez N, Oberyszyn TM and Hall BM: Interleukin-6 induces an epithelial-mesenchymal transition phenotype in human breast cancer cells. Oncogene 28: 2940-2947, 2009

22. Sansone P, Storci G, Tavolari S, Guarnieri T, Giovannini C, Taffurelli M, Ceccarelli C, Santini D, Paterini P, Marcu KB, et al: IL-6 triggers malignant features in mammospheres from human ductal breast carcinoma and normal mammary gland. J Clin Invest 117: 3988-4002, 2007.

23. Katanov C, Lerrer S, Liubomirski Y, Leider-Trejo L, Meshel T, Bar J, Feniger-Barish R, Kamer I, Soria-Artzi G, Kahani H, et al: Regulation of the inflammatory profile of stromal cells in human breast cancer: Prominent roles for TNF- $\alpha$ and the NF- $\mathrm{kB}$ pathway. Stem Cell Res Ther 6: 87, 2015.

24. DeNardo DG and Coussens LM: Inflammation and breast cancer. Balancing immune response: Crosstalk between adaptive and innate immune cells during breast cancer progression. Breast Cancer Res 9: 212,2007.
25. Goto S, Sato M, Kaneko R, Itoh M, Sato S and Takeuchi S: Analysis of Th1 and Th2 cytokine production by peripheral blood mononuclear cells as a parameter of immunological dysfunction in advanced cancer patients. Cancer Immunol Immunother 48: 435-442, 1999.

26. Idowu MO, Kmieciak M, Dumur C, Burton RS, Grimes MM, Powers CN and Manjili MH: CD44(+)/CD24(-/low) cancer stem/progenitor cells are more abundant in triple-negative invasive breast carcinoma phenotype and are associated with poor outcome. Hum Pathol 43: 364-373, 2012.

27. Kim HJ, Kim MJ, Ahn SH, Son BH, Kim SB, Ahn JH, Noh WC and Gong G: Different prognostic significance of CD24 and CD44 expression in breast cancer according to hormone receptor status. Breast 20: 78-85, 2011

28. Mylona E, Giannopoulou I, Fasomytakis E, Nomikos A, Magkou C, Bakarakos P and Nakopoulou L: The clinicopathologic and prognostic significance of CD44(+)/CD24(-/low) and CD44/CD24+ tumor cells in invasive breast carcinomas. Hum Pathol 39: 1096-1102, 2008.

29. Abraham BK, Fritz P, McClellan M, Hauptvogel P, Athelogou M and Brauch $\mathrm{H}$ : Prevalence of $\mathrm{CD} 44^{+} / \mathrm{CD} 24^{-}$/low cells in breast cancer may not be associated with clinical outcome but may favor distant metastasis. Clin Cancer Res 11: 1154-1159, 2005.

30. Al-Hajj M, Wicha MS, Benito-Hernandez A, Morrison SJ and Clarke MF: Prospective identification of tumorigenic breast cancer cells. Proc Natl Acad USA 100: 3983-3988, 2003.

31. Jiang $X$ and Shapiro DJ: The immune system and inflammation in breast cancer. Mol Cell Endocrinol 382: 673-682, 2014.

32. Tkach M, Coria L, Rosemblit C, Rivas MA, Proietti CJ, Díaz Flaqué MC, Beguelin W, Frahm I, Charreau EH, Cassataro J, et al: Targeting Stat 3 induces senescence in tumor cells and elicits prophylactic and therapeutic immune responses against breast cancer growth mediated by NK cells and CD4 ${ }^{+} \mathrm{T}$ cells. J Immunol 189: $1162-1172,2012$.

33. Wang B, Zaidi N, He LZ, Zhang L, Kuroiwa JM, Keler T and Steinman RM: Targeting of the non-mutated tumor antigen HER 2/neu to mature dendritic cells induces an integrated immune response that protects against breast cancer in mice. Breast Cancer Res 14: R39, 2012.

34. Mamessier E, Sylvain A, Thibult ML, Houvenaeghel G, Jacquemier J, Castellano R, Gonçalves A, André P, Romagné F, Thibault G, et al: Human breast cancer cells enhance self tolerance by promoting evasion from NK cell antitumor immunity. J Clin Invest 121:3609-3622, 2011.

35. Tsukerman P, Stern-Ginossar N, Gur C, Glasner A, Nachmani D, Bauman Y, Yamin R, Vitenshtein A, Stanietsky N, Bar-Mag T, et al: MiR-10b downregulates the stress-induced cell surface molecule MICB, a critical ligand for cancer cell recognition by natural killer cells. Cancer Res 72: 5463-5472, 2012.

36. Jiang X, Ellison SJ, Alarid ET and Shapiro DJ: Interplay between the levels of estrogen and estrogen receptor controls the level of the granzyme inhibitor, proteinase inhibitor 9 and susceptibility to immune surveillance by natural killer cells. Oncogene 26: 4106-4114, 2007.

37. Bargou RC, Wagener C, Bommert K, Mapara MY, Daniel PT, Arnold W, Dietel M, Guski H, Feller A, Royer HD and Dorken B: Overexpression of the death-promoting gene bax-alpha which is downregulated in breast cancer restores sensitivity to different apoptotic stimuli and reduces tumor growth in SCID mice. J Clin Invest 97: 2651-2659, 1996.

38. Liu S, Lachapelle J, Leung S, Gao D, Foulkes WD and Nielsen TO: CD8 ${ }^{+}$lymphocyte infiltration is an independent favorable prognostic indicator in basal-like breast cancer. Breast Cancer Res 14: R48, 2012.

39. Mahmoud SM, Paish EC, Powe DG, Macmillan RD, Grainge MJ, Lee AH, Ellis IO and Green AR: Tumor-infiltrating CD8 ${ }^{+}$ lymphocytes predict clinical outcome in breast cancer. J Clin Oncol 29: 1949-1955, 2011 